\title{
Disseminated Langerhans' cell histiocytosis and massive protein-losing enteropathy
}

T.M. Santos-M achado, L.M. Cristófani, M.T.A. Almeida, P.T. Maluf, P.A. Costa, M.A. Pereira, J.L.B.C. Brito and V. Odone-Filho
Instituto da Criança, Hospital das Clínicas,

Faculdade de Medicina, U niversidade de São Paulo,

São Paulo, SP, Brasil

\section{Correspondence \\ V. Odone Filho \\ Instituto da Criança \\ Hospital das Clínicas, FM, USP \\ Av. Dr. Eneas C. Aguiar, 647 \\ 05403-900 São Paulo, SP \\ Brasil \\ Fax: + 55-11-853-2602 \\ Research partially supported by the Centro de Estudos Prof. Pedro de Alcântara and Fundação Maksoud para o Desenvolvimento da Cirurgia Pediátrica. Publication supported by FAPESP.}

\section{Abstract}

Symptomatic involvement of the gastrointestinal (GI) tract as a prominent symptom in Langerhans' cell histiocytosis ( $\mathrm{LCH})$ is uncommon, occurring in less than 1 to $5 \%$ of all cases, even when the disease is in its disseminated form. Up to now, there have been reports of 18 cases of LCH with GI manifestations, including our 2 cases, with diarrhea (77.7\%), protein-losing enteropathy $(33.3 \%)$ and bloody stool being the most frequent findings. The authors present two patients with severe diarrhea and refractory hypoalbuminemia, and with the protein-losing enteropathy documented by $\mathrm{Cr}^{51}$-labeled albumin studies. A review of the literature indicated that the presence of GI symptoms is often associated with systemic disease as well as with poor prognosis, mainly under 2 years of age. Radioisotopes are useful for documenting protein loss in several diseases with high specificity and sensitivity, and their utilization in the cases reviewed here permitted diagnoses in 6 children, as well as improved therapeutic management.

\section{Key words}

- Langerhans' cell histiocytosis

- Histiocytosis X

- Gastrointestinal involvement

- Protein-losing enteropathy

- Hypoalbuminemia

- $\mathrm{Cr}^{51}$-labeled albumin test

\section{Introduction}

In 1953, Lichtenstein (1) introduced the term histiocytosis $\mathrm{X}$ to integrate HandSchüller-Christian syndrome, Letterer-Siwe disease, and eosinophilic granuloma of the bone, a group of diseases with similar histopathological characteristics. In 1973, histiocytosis $\mathrm{X}$ was described as local proliferation as well as dissemination of Langerhans' histiocytes (2). Since Langerhans' histiocytes are considered to be the main lesion cells in this disorder, in 1983, Risdall et al. (3) suggested naming the disease Langerhans' cell histiocytosis $(\mathrm{LCH})$.

Confidence levels for the diagnosis of LCH have been established by the Histiocyte Society (4). A "presumptive diagnosis" is based on the examination of conventionally processed tissue that presents a lesion which is consistent with those described in the literature, such as Langerhans' cells (large cells that have abundant, pale cytoplasm, with folded or grooved nuclei). A higher confidence level for diagnosis, simply called a "diagnosis", is arrived at when findings from a presumptive diagnosis are complemented by the presence of at least two of the follow- 
ing characteristics: immunohistochemical confirmation with staining for S-100 protein, ATPase, alpha-D-mannosidase, or peanut lectin binding. A "definite diagnosis" requires the presence of Birbeck granules in the lesion cells upon electron microscopic examination or demonstration of T6 (CD1A) antigenic determinants on the surface of the lesion cells.

Although the literature on $\mathrm{LCH}$ is extensive, this disorder in combination with gastrointestinal (GI) involvement is rarely described (5-7). Even in these few cases, GI complications seldom appear as prominent clinical manifestations. The main clinical findings regarding intestinal disease include diarrhea (sometimes bloody) and proteinlosing enteropathy (8).

In this study, we report two patients with disseminated $\mathrm{LCH}$ admitted to the Instituto da Criança (ICr). Both cases involved massive protein-losing enteropathy demonstrated by tests performed with $\mathrm{Cr}^{51}$-labeled albumin. Based on our experience and on a review of the existing literature on GI involvement in $\mathrm{LCH}$, we discuss the role of enteral protein loss in the maintenance of hypoalbuminemia as an aggravating factor in patients with disseminated $\mathrm{LCH}$.

\section{Case reports}

\section{Case 1}

A 2-year-old white girl with a three-month history of diarrhea, daily fever, anasarca, oliguria, an ulcerated lesion of the scalp, disseminated petechiae, hepatomegaly and splenomegaly, as well as a tumor on the left frontal region was examined in our service.

Initial laboratory findings revealed: hemoglobin level $=3.7 \mathrm{~g} / \mathrm{dl}$; hematocrit value $=12 \%$; white blood cell count $=1,900 / \mathrm{mm}^{3}$; platelet count $<5,000 / \mathrm{mm}^{3}$; blood urea nitrogen level $=137 \mathrm{mg} / \mathrm{dl}$ (considered as dehydration); creatinine clearance level $=0.5 \mathrm{mg}$ / $\mathrm{dl}$; serum albumin level $=1.1 \mathrm{~g} / \mathrm{dl}$; total bilirubin level $=4.6 \mathrm{mg} / \mathrm{dl}$ (or $3.5 \mathrm{mg} / \mathrm{dl}$ of direct bilirubin); prothrombin activity $=$ $24.4 \%$; skin and bone marrow biopsy results consistent with LCH.

The patient continued with anasarca, persistent hypoalbuminemia, and massive diarrhea, in spite of several blood and albumin transfusions, as well as administration of parenteral nutritional support. Enteral protein loss was investigated by $\mathrm{Cr}^{51}$-labeled albumin tests. The dose administered was equivalent to 0.5 microcurie $/ \mathrm{kg}$. Results revealed an enteral loss equivalent to $81.5 \mathrm{ml}$ of plasma per day (normal value $=14.6 \pm 9$ $\mathrm{ml} /$ day).

The patient did not respond to support with daily albumin. Her hypoalbuminemia persisted in spite of treatment with vinblastine, methotrexate, prednisone, and etoposide. She died two months after diagnosis due to respiratory and cardiac failure, digestive hemorrhage, and hemorrhagic ascites.

\section{Case 2}

A 2-year-old white boy with a six-month history of jaundice, fever, pallor, diarrhea, loss of weight, hepatomegaly, ascites, skin and mucosal lesions, and diabetes insipidus was examined in our service.

Laboratory findings revealed: hemoglobin level $=11.9 \mathrm{~g} / \mathrm{dl}$; white blood cell count $=22,200 / \mathrm{mm}^{3}$; platelet count $=310,000 /$ $\mathrm{mm}^{3}$; blood urea nitrogen level $=43 \mathrm{mg} / \mathrm{dl}$ (considered as dehydration); creatinine clearance level $=0.6 \mathrm{mg} / \mathrm{dl}$; total bilirubin level $=$ $10.3 \mathrm{mg} / \mathrm{dl}$ (or $9.7 \mathrm{mg} / \mathrm{dl}$ of direct bilirubin); prothrombin activity $=38 \%$; serum albumin level $=2.1 \mathrm{~g} / \mathrm{dl}$; biopsy results of a palate lesion consistent with $\mathrm{LCH}$.

The patient continued with anasarca, persistent hypoalbuminemia, and massive diarrhea in spite of several blood and albumin transfusions, as well as administration of parenteral nutritional support. Enteral protein loss, determined by $\mathrm{Cr}^{51}$-labeled albumin tests, as done in case 1 , revealed an 
enteral loss equivalent to $75 \mathrm{ml}$ of plasma per day.

Despite daily albumin administration, diarrhea and hypoalbuminemia persisted. Treatment with prednisone, cyclophosphamide, chlorambucil, and hydroxyurea was unsuccessful. The patient developed severe thrombocytopenia and died five months after diagnosis.

The families of both children refused permission for further studies at autopsies.

\section{Discussion}

LCH with GI tract involvement is rare and is usually recognized only at post mortem examination of patients with multi-organ lesions (9-13). Although most studies that have included large series of patients with disseminated LCH do not report GI symptoms $(6,7,14)$, two children admitted to our service had diarrhea, representing $4.6 \%$ of all patients with LCH seen at our institution between 1976 and 1991.

In spite of the difficulty in assessing the frequency of GI involvement, Hyams et al. (15) reported GI symptoms in less than $1 \%$ of all patients, based on a review of other series that included 145 patients $(12,16-18)$. Skopnic et al. (19) showed an estimated incidence of $5 \%$ of GI tract involvement in disseminated LCH. Idliki and Hamoudi (20) discussed a case with primary LCH of the bowel at the time of diagnosis.

Virtually all children described in the literature had multi-systemic disease, but GI disorders were rarely a prominent feature. Typically, LCH occurs either at sites in the skin or lymph nodes, where Langerhans' cells or their precursors thrive, or in organs such as the lung or liver, as a result of certain pathological conditions $(21,22)$. Although it would seem that GI tract invasion would be related to multi-systemic, widespread disease, Keeling and Harries (11) have demonstrated that histological involvement of the GI tract in LCH may be more frequent than the classical textbook descriptions of this disease suggest.

A summary of 18 reported cases, including ours, is presented in Table 1. Patients' ages ranged from the neonatal period (congenital form) to 3 years, with a median age of 4 months. Two thirds of the affected children were females. Table 2 outlines the most frequent clinical manifestations of LCH with GI complications, including diarrhea (sometimes bloody), vomiting, and protein-losing enteropathy. Malabsorption and intestinal ulceration with melena and perforation were rarely described (11,23-25). As Table 2 illustrates, $\mathrm{LCH}$ patients with intestinal disease present a high frequency $(33.3 \%)$ of protein-losing enteropathy.

Even though GI tract dysfunction has not been identified as critical for prognosis (26), most of the patients affected by it have fared poorly, probably due to multi-systemic dissemination of the disease. According to Jaffe et al. (8), the definitive diagnosis of LCH based on the Histiocyte Society criteria (4) is usually made beforehand at another site. Although histologic findings confirm the presence of S-100 protein, clinical findings are often sufficient to document GI involvement.

After confirming our diagnoses by positive stains of S-100 protein from skin biopsies, we documented the protein loss with $\mathrm{Cr}^{51}$-labeled albumin tests, a method that is widely used to identify enteric protein loss (27).

$\mathrm{Cr}^{51}$-labeled albumin is neither significantly absorbed nor secreted into the GI tract. Following intravenous administration of $\mathrm{Cr}^{51}$-labeled albumin, normal adult subjects excrete 0.1 to $0.7 \%$ of the administered radioactive element in their stools during a subsequent four-day period (28). Pediatric patients with enteric protein loss excrete a greater amount of the administered dose during similar periods $(28,29)$. No false-negative or false-positive results were found in over 200 studies that used $\mathrm{Cr}^{51}$-labeled albu- 
Table 1 - Clinical manifestations of GI tract involvement in LCH in 18 children, including our 2 cases.

*Congenital; EM = electron microscopy; PLE = protein-losing enteropathy; ? = not reported.

\begin{tabular}{|c|c|c|c|c|c|}
\hline $\begin{array}{l}\text { Case/author } \\
\text { (Reference) }\end{array}$ & $\begin{array}{l}\text { Age at } \\
\text { diagnosis }\end{array}$ & Sex & $\begin{array}{l}\text { Clinical } \\
\text { findings }\end{array}$ & $\begin{array}{l}\text { Diagnostic } \\
\text { method }\end{array}$ & $\begin{array}{l}\text { Follow-up } \\
\text { after diagnosis }\end{array}$ \\
\hline 1 Keeling and Harries (11) & 2 months & $\mathrm{F}$ & $\begin{array}{l}\text { Diarrhea, } \\
\text { malabsorption, PLE }\end{array}$ & Presumptive & $\begin{array}{l}\text { Death, } \\
5.8 \text { months }\end{array}$ \\
\hline 2 Tamura et al. (30) & 1 day & M & PLE & EM & $\begin{array}{l}\text { Death, } \\
1.5 \text { months }\end{array}$ \\
\hline 3 Deprettere et al. (31) & 8 months & $\mathrm{F}$ & Diarrhea (bloody) & EM & $\begin{array}{l}\text { Death, } \\
5.0 \text { months }\end{array}$ \\
\hline 4 Hyams et al. (15) & 4 months & $\mathrm{F}$ & Diarrhea (bloody) & EM, CD1A & $\begin{array}{l}\text { Death, } \\
5.5 \text { months }\end{array}$ \\
\hline 5 Idliki and Hamoudi (20) & 9 months & $\mathrm{F}$ & $\begin{array}{l}\text { Diarrhea, } \\
\text { malabsorption }\end{array}$ & S-100 & $\begin{array}{l}\text { Death, } \\
2.5 \text { years }\end{array}$ \\
\hline 6 Sutphen and Fechner (23) & 3 years & $\mathrm{F}$ & $\begin{array}{l}\text { Diarrhea, intestinal } \\
\text { perforation }\end{array}$ & Presumptive & $\begin{array}{l}\text { Alive, } \\
5.0 \text { years }\end{array}$ \\
\hline 7 Raney J r and D'Angio (13) & $?$ & $?$ & $?$ & $?$ & $\begin{array}{l}\text { Alive, } \\
7.2 \text { years }\end{array}$ \\
\hline 8 Egeler et al. (25) & 6 months & M & $\begin{array}{l}\text { Diarrhea (bloody), } \\
\text { vomiting }\end{array}$ & EM, CD1A & $\begin{array}{l}\text { Alive, } \\
2.0 \text { years }\end{array}$ \\
\hline 9 Egeler et al. (25) & 10 months & $\mathrm{F}$ & PLE, vomiting & EM & $\begin{array}{l}\text { Death, } \\
1.2 \text { years }\end{array}$ \\
\hline 10 Egeler et al. (25) & 4 months & M & Diarrhea, vomiting & EM & $\begin{array}{l}\text { Death, } \\
1.5 \text { years }\end{array}$ \\
\hline 11 Lee et al. (22) & 3 weeks* & $\mathrm{F}$ & Diarrhea (bloody) & EM, CD1A & $\begin{array}{l}\text { Death, } \\
10.0 \text { months }\end{array}$ \\
\hline 12 Lee et al. (22) & 1 month* & $\mathrm{F}$ & Diarrhea (bloody) & EM, CD1A & $\begin{array}{l}\text { Death, } \\
5.5 \text { months }\end{array}$ \\
\hline 13 Boccon-Gibod et al. (24) & 2 weeks* & M & PLE & EM, CD1A & $\begin{array}{l}\text { Death, } \\
1.0 \text { month }\end{array}$ \\
\hline 14 Boccon-Gibod et al. (24) & 28 months & $\mathrm{F}$ & Diarrhea, melena & EM, CD1A & $\begin{array}{l}\text { Alive, } \\
1.5 \text { years }\end{array}$ \\
\hline 15 Pittschieler et al. (17) & 12 months & $\mathrm{F}$ & Diarrhea, vomiting & EM, CD1A, S-100 & $\begin{array}{l}\text { Death, } \\
1.0 \text { month }\end{array}$ \\
\hline 16 Skopnik et al. (19) & 10 months & $\mathrm{F}$ & Diarrhea (bloody) & $?$ & $?$ \\
\hline $\begin{array}{l}17 \text { Santos-Machado et al. } \\
\text { (present study) }\end{array}$ & 24 months & $\mathrm{F}$ & PLE, diarrhea & S-100 & $\begin{array}{l}\text { Death, } \\
2.0 \text { months }\end{array}$ \\
\hline $\begin{array}{l}18 \text { Santos-Machado et al. } \\
\text { (present study) }\end{array}$ & 24 months & M & PLE, diarrhea & S-100 & $\begin{array}{l}\text { Death, } \\
5.0 \text { months }\end{array}$ \\
\hline
\end{tabular}

Table 2 - Clinical and laboratory findings (\%) in 18 LCH patients with $\mathrm{Gl}$ tract symptoms, including our 2 cases.

\begin{tabular}{lrr}
\hline Symptoms & $\begin{array}{c}\text { Number } \\
\text { of cases }\end{array}$ & $\%$ \\
\hline Diarrhea & 14 & 77.7 \\
Protein-losing enteropathy & 6 & 33.3 \\
Bloody stool & 6 & 33.3 \\
Vomiting & 4 & 22.2 \\
Malabsorption & 2 & 11.1 \\
Melena & 1 & 5.5 \\
Perforation & 1 & 5.5 \\
No information available & 1 & 5.5
\end{tabular}

min (27). Our patients presented massive protein losses of $81.5 \mathrm{ml} /$ day, while the normal value is $14.6 \pm 9 \mathrm{ml} /$ day.

In six cases reviewed in the literature in which protein-losing enteropathy was present, all patients $(100 \%)$ died. Deaths occurred 1 month to 1.5 years after diagnosis. Patients who did not experience protein loss lived longer, possibly due to the absence of refractory hypoalbuminemia. Tamura et al. (30) believe that loss of serum protein through the bowel is another contributing factor to the poor prognosis of patients with multi- 
systemic LCH lesions.

We suggest the use of $\mathrm{Cr}^{51}$-labeled albu$\min$ to investigate protein-losing enteropathy in patients with disseminated $\mathrm{LCH}$, with or without important GI symptoms. The iden- tification of protein-losing enteropathy, at least in the most severe cases, allows for better clinical management of patients with disseminated LCH.

\section{References}

1. Lichtenstein L (1953). Histiocytosis X: Integration of eosinophilic granuloma of the bone, "Letterer-Siwe disease", and "Schüller-Christian disease" as related manifestations of a single nosologic entity. Archives of Pathology, 56: 84-102.

2. Nezelof $C$, Basset $F \&$ Rousseau MF (1973). Histiocytosis X: Histogenetic arguments for a Langerhans' cell origin. Biomedicine, 18: 365-371.

3. Risdall RJ , Dehner LP, Duray P, Kobrinsky N, Robison L \& Nesbit ME (1983). Histiocytosis X (Langerhans' cell histiocytosis). Archives of Pathology and Laboratory Medicine, 107: 59-63.

4. Writing Group of the Histiocyte Society (1987). Histiocytosis syndromes in children. Lancet, 1: 208-209.

5. Lahey ME (1962). Prognosis in reticuloendotheliosis in children. J ournal of Pediatrics, 60: 664-671.

6. Nesbit ME (1986). Current concepts and treatment of histiocytosis X (Langerhans' cell histiocytosis). In: Voûte PA, Barret A, Bloom HJ, Lemerle J \& Neidhardt MK (Editors), Cancer in Children - Clinical Management. Vol. 1. Springer-Verlag, Berlin, 176-184.

7. Nezelof $C$, Frileux-Herbert $F \&$ CronierSachot J (1979). Disseminated histiocytosis X. Analysis of prognostic factors based on a retrospective study of 50 cases. Cancer, 44: 1824-1834.

8. J affe R, Wollman MR, Kocoshis S, Penchansky L \& Gilbert-Barness E (1993). Pathological cases of the month. Langerhans' cell histiocytosis with gastrointestinal involvement. American J ournal of Diseases in Children, 147: 79-80.

9. Daneshbod K \& Kissane J M (1978). Idiopathic differentiated histiocytosis. American J ournal of Clinical Pathology, 70: 381 389.

10. Favara BE \& J affe R (1987). Pathology of Langerhans' cell histiocytosis. Hematol-
ogy/Oncology Clinics of North America, 1: 75-97.

11. Keeling J W \& Harries J T (1973). Intestinal malabsorption in infants with histiocytosis X. Archives of Disease in Childhood, 48: 350-354.

12. Oberman HA (1961). Idiopathic histiocytosis: A clinicopathologic study of 40 cases and review of the literature on eosinophilic granuloma of the bone, HandSchüller-Christian disease and LettererSiwe disease. Pediatrics, 28: 307-327.

13. Raney J r RB \& D'Angio GJ (1989). Langerhans' cell histiocytosis (histiocytosis X). Experience at the Children's Hospital of Philadelphia 1970-1984. Medical and Pediatric Oncology, 17: 20-28.

14. Lahey ME (1975). Histiocytosis X - an analysis of prognostic factors. J ournal of Pediatrics, 87: 184-189.

15. Hyams J S, Haswell JE, Gerber MA \& Berman MM (1985). Colonic ulceration in histiocytosis X. J ournal of Pediatric Gastroenterology and Nutrition, 4: 286-290.

16. Lucaya J (1971). Histiocytosis X. American J ournal of Diseases in Children, 121: 289-295.

17. Pittschieler K, Radetti G, Egarter E \& Mengarda G (1989). Chronischer Durchfall als Hauptsymptom einer Histiozytose $X$. Helvetica Paediatrica Acta, 43: 467-471.

18. Talbot ML (1974). Histiocytosis X. American Surgeon, 40: 89-96.

19. Skopnik H, Greven P, Füzesi L, Mertens R \& Heiman G (1991). Gastrointestinale Symptome bei disseminierten Langerhans-Zell-Histiozytosen. Kasuistik and Literaturüberchit. Monatsschrift für Kinderheilkunde, 139: 239-243.

20. Idliki $O \&$ Hamoudi $A B$ (1984). Primary histiocytosis $\mathrm{X}$ of bowel. Pediatric Pathology, 2: 492 (Abstract).

21. Basset F, Soler P \& Hance AJ (1986). The Langerhans' cell in human pathology. Annals of the New York Academy of Sci- ences, 465: 324-329.

22. Lee RG, Braziel RM \& Stenzel P (1990). Gastrointestinal involvement in Langerhans' cell histiocytosis (histiocytosis X): Diagnosis by rectal biopsy. Modern $\mathrm{Pa}$ thology, 3: 154-157.

23. Sutphen J L \& Fechner RE (1986). Chronic gastroenteritis in a patient with histiocytosis X. J ournal of Pediatric Gastroenterology and Nutrition, 5: 324-328.

24. Boccon-Gibod LA, Krichen HA, CarlierMercier LMB, Salaun J F, Fontaine J L \& Leuerger AR (1992). Digestive tract involvement with exudative enteropathy in Langerhans' cell histiocytosis. Pediatric Pathology, 12: 515-524.

25. Egeler RM, Schipper ME \& Heymas HS (1990). Gastrointestinal involvement in Langerhans' cell histiocytosis (histiocytosis X): A clinical report of three cases. European J ournal of Pediatrics, 149: 325329.

26. Lahey ME (1981). Prognostic factors in histiocytosis X. American J ournal of Pediatric Hematology/Oncology, 3: 57-60.

27. Waldman TA (1966). Protein-losing enteropathy. Gastroenterology, 50: 422-443.

28. Waldman TA (1961). Gastrointestinal protein loss demonstrated by $\mathrm{Cr}^{51}$-labeled albumin. Lancet, 2: 121-123.

29. Waldman TA \& Wochner RD (1963). The use of $\mathrm{Cr}^{51}$-labeled albumin in the study of protein-losing enteropathy. Protides of the Biological Fluids, Proceedings of the Colloquium, 11: 224-226.

30. Tamura $\mathrm{T}$, Umetsu $\mathrm{M}$, Motoya $\mathrm{H} \&$ Yokoyama S (1980). Congenital LettererSiwe disease associated with protein-losing enteropathy. European J ournal of Pediatrics, 136: 77-80.

31. Deprettere A, Aevoet G, Van Acker KJ \& DockX P (1983). Intractable diarrhea in histiocytosis X. Helvetica Paediatrica Acta, 38: 291-294. 